\title{
Reversed Micellar Extraction of Hen Egg Lysozyme
}

\author{
SHU-TING CHOU and BEEN-HUANG CHIANG
}

\begin{abstract}
Eggwhite was diluted to 10 times its original volume with 50 mM phosphate buffer (pH 9.2) containing $0.1 \mathrm{M}$ potassium chloride. The aqueous solution was mixed with an equal volume of isooctane containing $50 \mathrm{mM}$ bis-(2-ethylhexyl) sodium sulfosuccinate at $10^{\circ} \mathrm{C}$ for $50 \mathrm{~min}$. After extraction, the organic phase containing lysozyme was separated from the aqueous phase and mixed with an equal volume of $\mathbf{5 0}$ $\mathrm{mM}$ phosphate buffer $(\mathrm{pH} 11.8)$ containing $1 \mathrm{M}$ potassium chloride. Backward extraction was then performed at $30^{\circ} \mathrm{C}$ for $\mathbf{4 5} \mathrm{min}$. The procedures recovered $\mathbf{9 0 \%}$ lysozyme from the eggwhite. The specific activity of the extract was near 73,000 units/mg.

Key Words: hen, eggwhite, lysozyme, reversed micelles
\end{abstract}

\section{INTRODUCTION}

REVERSED MICELLES ARE AGGREGATES OF SURFACTANT molecules containing an inner core of water molecules, dispersed in an organic solvent providing an effective separation technology. Many biological products can be solubilized into the core water without loss in activity (Luisi, 1985; Kinugasa et al., 1992). The major application of reversed micelles is the extraction of proteins such as enzymes. Many enzymes can be solubilized in reversed micelle aggregates, including $\alpha$-chymotrypsin (Jolivalt et al.1990; Marcozzi et al., 1991); lipases (Aires-Barros and Cabral, 1991; Taipa et al., 1992); proteases (Rahaman et al., 1988); $\alpha$-amylase (Chang and Chen, 1995a; Krei et al., 1995; Brandani et al., 1996); trypsin (Chang and Chen, 1995b) and lysozymes (Kinugasa et al., 1991, 1992; Chang et al., 1994; Lye et al., 1995; Naoe et al., 1995).

Among enzymes studied to assess feasibility of separation and purification by reversed micelles, lysozyme is an important enzyme substrate because of its broad potential for food and clinical applications. Several factors affecting the separation efficiency of lysozyme by reversed micelles have been studied, including $\mathrm{pH}$ and ionic strength of the aqueous phase containing lysozyme (Goklen and Hatton, 1987), concentration of surfactant in the organic phase (Dekker et al., 1989; Kelley et al., 1993), extraction temperature (Kunieda and Shinoda, 1980) and time (Dekker et al., 1986). However, previous studies either focused on the partitioning of lysozyme into the reversed micellar solution or the stability of lysozyme during extraction. They were also based on a clean model system prepared by dissolving pure lysozyme in a phosphate buffer, which may not be indicative of separation from biological materials.

When employing reversed micelles to separate lysozyme from a biological material, the existence of other proteins would inevitably interfere with the separation. Our objective was to apply reversed micellar extraction to extract lysozyme from hen eggwhite. Parameters which might affect the effectiveness of the extraction were investigated. The major criteria were the recovery rate and activity of lysozyme after extraction.

Authors Chou and Chiang are affiliated with the Graduate Institute of food Science \& Technology, National Taiwan Univ., Taipei, Taiwan, ROC. Address inquiries to Dr. B-H. Chiang.

\section{MATERIALS \& METHODS}

\section{Materials}

Hen eggs were obtained from a supermarket in Taipei. Lysozyme (E. C. 3.2.1.17. Mucopeptide $\mathrm{N}$-acetylmuramyl hydrolase) and $\mathrm{Mi}$ crococcus lysodeikticus were purchased from Sigma Chemical Co. (St. Louis, MO). Acetic acid and methanol were from Alps Chemical Co. (Taipei, Taiwan). Tetrabutylammonium bromide and polyacrylamide were from E. Merck Co. (Darmstadt, Germany). The protein assay dye reagent was obtained from Bio-Rad Co. (Hercules, CA). Other chemicals included bis-(2-ethylhexyl) sulfosuccinate sodium salt (also called Aerosol OT, or AOT) (Fluka AG Chemische Fabrik, Buchs, Switzerland), potassium chloride (Wako Pure Chemical Industries, Ltd., Osaka, Japan), sodium dodecyl sulfate (BDH Laboratory Supplies, Poole, England), and isooctane (Fisher Scientific Co., Pittsburgh, PA).

A $5 \mathrm{mg} / \mathrm{mL}$ aqueous lysozyme solution was prepared by dissolving lysozyme crystals in $50 \mathrm{mM}$ potassium phosphate buffer $(\mathrm{pH}$ 9.8). Other potassium phosphate buffer solutions ( $\mathrm{pH} 6$ to 11) containing various concentrations of potassium chloride $(0.05$ to $0.4 \mathrm{M})$ were then used to dilute the lysozyme solution 5 -fold to 10 -fold. The hen eggwhite was also diluted with the $50 \mathrm{mM}$ buffer solutions of $\mathrm{pH} 6$ to 11 with potassium chloride concentrations from $0.05 \mathrm{M}$ to $0.4 \mathrm{M}$. The organic solution was prepared by dissolving AOT in isooctane to make a $50 \mathrm{mM}$ solution.

\section{Extraction procedure}

The reversed micellar extraction consisted of two steps, forward extraction and backward extraction. The forward extraction was carried out in a stoppered 50-mL centrifuge tube. Equal volumes (ca. 8 $\mathrm{mL}$ ) of the organic solution and aqueous solution were mixed in the tube and shaken in a constant temperature water bath $\left(5\right.$ to $\left.30^{\circ} \mathrm{C}\right)$ for selected times ( 20 to $60 \mathrm{~min}$ ). The resulting mixtures were then centrifuged at $3000 \mathrm{rpm}(1100 \times g)$ for $5 \mathrm{~min}$. The upper layer $(5 \mathrm{~mL})$ (reversed micellar solution) was taken for a subsequent backward extraction.

To the reversed micellar solution from the forward extraction, an equal volume $(5 \mathrm{~mL})$ of the $50 \mathrm{mM}$ phosphate buffer $(\mathrm{pH} 11.8)$ was added. This mixture was shaken in a water bath at $30^{\circ} \mathrm{C}$ for $45 \mathrm{~min}$. After centrifugation, the lower aqueous layer was collected and analyzed for lysozyme content.

\section{Analytical}

The protein concentration was analyzed by a procedure based on the Bradford dye-binding method (Bradford, 1976). Bio-Rad protein assay dye reagent $(5 \mathrm{~mL})$ was mixed with $0.1 \mathrm{~mL}$ of the protein solution. The optical density of the mixture at $595 \mathrm{~nm}$ was observed spectrometrically to determine the protein concentration using a standard curve obtained by recording the $\mathrm{OD}_{595 \mathrm{~nm}}$ of pure lysozyme solutions. A Micrococcus lysodeikticus turbidity method suggested by Sigma Chemical Co. was used for determining lysozyme activity. The recovery of lysozyme was estimated by:

Lysozyme recovery $(\%)=$

[(Total activity of lysozyme in the aqueous phase after extraction)/ (Total activity of lysozyme in the aqueous phase before extraction) $] \times 100$. 
Sodium dodecyl sulfate-polyacrylamide gel electrophoresis (SDSPAGE) was carried out by the method of Laemmli (1970) using 15\% polyacrylamide separating gel and $4 \%$ stacking gel. Samples containing 1 to $2 \mathrm{mg}$ protein/ $\mathrm{mL}$ were dissolved in equal volumes of buffer solution (0.1M Tris-HCl, pH 6.8, 4 mM EDTA, 20\% glycerol, $0.05 \%$ bromophenol blue, $4 \%$ SDS, and $10 \% \beta$-mercaptoethanol), and heated at $100^{\circ} \mathrm{C}$ for $5 \mathrm{~min}$. Gels were stained with Coomassie Brilliant Blue R250 for detection of protein, and destained by diffusion in a solution containing $10 \%$ acetic acid, $20 \%$ methanol, and $70 \%$ water.

The residual AOT content in the extract was analyzed with an HPLC system (ICI Instrument Co., Victoria, Australia) and RI detector. The extract was separated on a $5 \mu \mathrm{m}, 220 \mathrm{~mm} \times 4.0 \mathrm{~mm} \mathrm{Li}-$ Chrospher RP-18 column (Merck Co., Darmstadt, Germany) at $30^{\circ} \mathrm{C}$, and eluted at $1 \mathrm{~mL} / \mathrm{min}$ with ethanol/distilled water $(\mathrm{V}: \mathrm{V}=78: 22)$ containing $2 \mathrm{mM}$ tetrabutylammonium bromide. The Duncan multiple range test was used for analyzing the data statistically (Duncan, 1955). Significance of differences was defined at $p<0.05$.

\section{RESULTS \& DISCUSSION}

\section{Dilution of eggwhite}

Extraction of lysozyme by reversed micelles was first performed on the hen eggwhite without dilution. However, the lysozyme either remained in the aqueous phase or formed insoluble aggregates at the organic solution-aqueous solutions interface. It was suspected that interactions between lysozyme and other eggwhite proteins (Nakai and Kason, 1974; Kato et al., 1975) might have interfered.

Dilution of eggwhite with $50 \mathrm{mM}$ potassium phosphate buffer (pH 9.8) improved the extraction effectiveness (Table 1). Increasing the dilution factor increased lysozyme recovery. However, the recovery of lysozyme from eggwhite was much lower than recovery from the standard lysozyme solution. The reversed micelles recovered nearly $99 \%$ of lysozyme from the standard solution. However, when diluting the eggwhite to one-tenth of its initial concentration, the recovery of lysozyme from eggwhite was only about $50 \%$.

The specific activity of the lysozyme extracted from eggwhite remained at $\simeq 60,000$ units/mg, suggesting that the AOT/isooctane system selectively extracted lysozyme from eggwhite. In addition, the organic phase (AOT/isooctane) did not exert any adverse effect on the lysozyme molecules.

\section{Effect of pH on extraction of lysozyme}

The $\mathrm{pH}$ of the aqueous phase is one of the most important parameters affecting reversed micellar extraction (Goklen and Hatton, 1987; Leodidis, 1990; Leser and Luisi, 1990; Luisi, 1985). In general, the recovery of lysozyme increased with increasing $\mathrm{pH}$ value (Fig. 1), and reached a plateau at $\mathrm{pH} 9.2$. The isoelectric point of lysozyme is around 11. At pH 9.2, the lysozyme retains mainly positive charges on its surface. The reversed micelles formed by the anionic surfactant Aerosol OT (AOT) display a surface of negative charge surrounding a polar core. Because of the electrostatic interactions, the lysozyme was transferred from the aqueous phase to the micellar solution (Goklen and Hatton, 1987; Leodidis, 1990; Leser and Luisi, 1990; Luisi, 1985; Kinugasa et al., 1991). When the pH of the aqueous phase approached the isoelectric point of lysozyme, the positively charged groups of lysozyme molecules were gradually neutralized, and the electrostatic interaction between lysozyme and AOT were diminished. As a result, solubilization of lysozme within the polar core of the reversed micelles decreased sharply (Fig. 1).

The optimum $\mathrm{pH}$ of the aqueous phase for extracting lysozyme from eggwhite was $\simeq 9.2$. However, the recovery only amounted to $60 \%$. The electrostatic interaction between lysozyme and AOT at $\mathrm{pH} 9.2$ were not effective in displacing the interactions between lysozyme and other eggwhite proteins.

The extraction efficiency for eggwhite lysozyme was not altered when the $\mathrm{KCl}$ concentration was increased from $0.05 \mathrm{M}$ to
Table 1-Effect of dilution on extraction of lysozyme

\begin{tabular}{ccccc}
\hline Dilution & \multicolumn{2}{c}{ Standard lysozyme solution } & \multicolumn{2}{c}{ Hen eggwhite } \\
\cline { 2 - 5 } factor & $\begin{array}{c}\text { Lysozyme } \\
\text { recovery (\%) }\end{array}$ & $\begin{array}{c}\text { Specific } \\
\text { activity } \\
\text { (units/mg) }\end{array}$ & $\begin{array}{c}\text { Lysozyme } \\
\text { recovery (\%) }\end{array}$ & $\begin{array}{c}\text { Specific } \\
\text { activity } \\
\text { (units/mg) }\end{array}$ \\
\hline 5 & $68.0^{\mathrm{d} *}$ & $60287^{\mathrm{a}}$ & $28.0^{\mathrm{i}}$ & $59132^{\mathrm{a}}$ \\
6 & $79.0^{\mathrm{c}}$ & $59360^{\mathrm{a}}$ & $31.0^{\mathrm{i}}$ & $59943^{\mathrm{a}}$ \\
7 & $86.5^{\mathrm{cb}}$ & $59605^{\mathrm{a}}$ & $35.0^{\mathrm{ih}}$ & $59066^{\mathrm{a}}$ \\
8 & $91.5^{\mathrm{ab}}$ & $60083^{\mathrm{a}}$ & $39.5^{\mathrm{gh}}$ & $59942^{\mathrm{a}}$ \\
9 & $95.5^{\mathrm{ab}}$ & $59763^{\mathrm{a}}$ & $47.0^{\mathrm{g}}$ & $60352^{\mathrm{a}}$ \\
10 & $98.4^{\mathrm{a}}$ & $59828^{\mathrm{a}}$ & $51.6^{\mathrm{ef}}$ & $58932^{\mathrm{a}}$ \\
\hline
\end{tabular}

a-iMeans within the same column with different superscripts are significantly different $(p<0.05)$.

$0.3 \mathrm{M}$ (Fig. 2). Since the interaction between lysozyme and other major eggwhite proteins, such as ovalbumin, is electrostatic in nature (Nakai and Kason, 1974), increasing the $\mathrm{KCl}$ concentration of the aqueous phase may decrease the interactions between lysozyme and other eggwhite proteins, and increase the extraction efficiency for lysozyme. However, an increase of salt concentration may lead to an electrostatic screening effect (Leodidis, 1990; Nishiki et al., 1993) which reduces the electrostatic interaction between lysozyme and AOT and decreases the size of the micelles, thus decreasing extraction efficiency. Our data suggested that the beneficial effect of decreasing eggwhite-protein interactions was counteracted by the electrostatic screening effect in the salt concentration range $0.10 \mathrm{M}$ to $0.30 \mathrm{M}$. When the salt concentration was increased to $0.30 \mathrm{M}$, the electric shielding effect became dominant, and the lysozyme recovery decreased significantly.

\section{Extraction temperature, time and lysozyme recovery}

Since the changes of $\mathrm{pH}$ and salt concentration in the aqueous solution did not increase the extraction efficiency, other operating parameters, including extraction temperature and time, were investigated. The recovery rate increased with the a decrease of extraction temperature (Fig. 3 ). At $10^{\circ} \mathrm{C}$, the recovery rate was $\simeq 65 \%$. Dekker et al. (1991) also studied the effect of temperature on reversed mi-

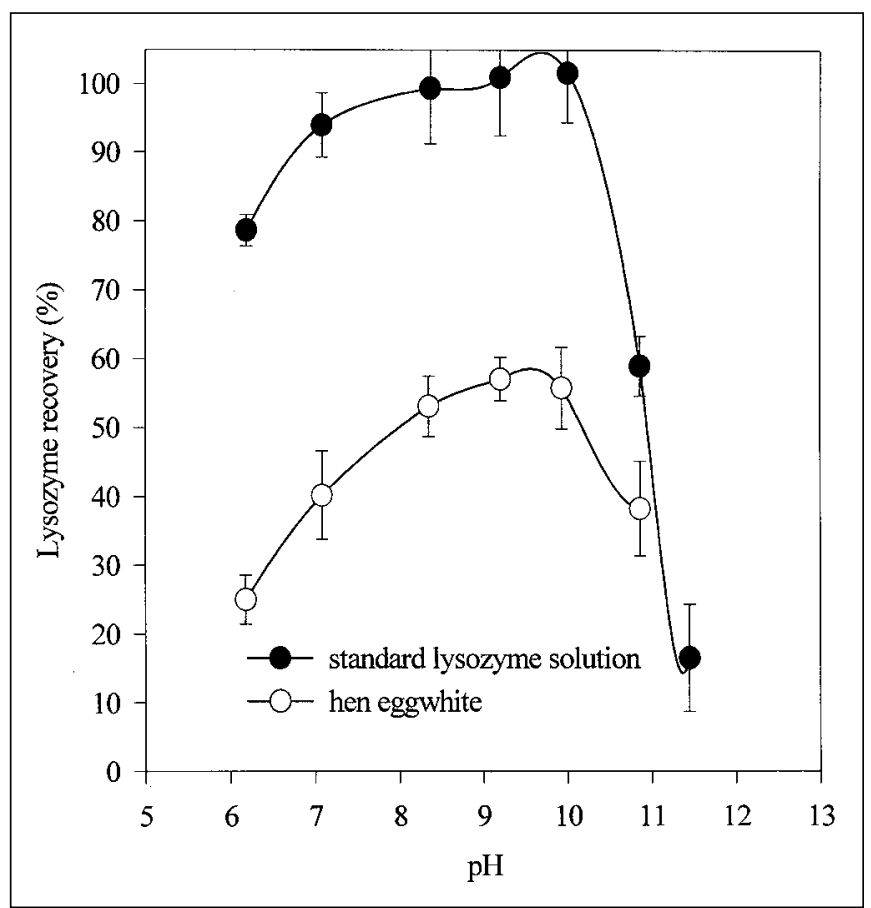

Fig. 1-pH relation to recovery of lysozyme during reversed micellar extraction. 
cellar extraction of enzymes and found that the maximum amount of aqueous phase which could be solubilized in the reversed micellar phase was a function of temperature. As the temperature increased the amount of solubilized aqueous solution decreased. Lowering extraction temperature, therefore, facilitated the extraction of lysozyme into the micellar phase.

Decreasing the extraction temperature increased the specific activity of lysozyme in the extract (Table 2). Although the mass transfer rates of the protein molecules in eggwhite were generally decreased with decreasing temperatures, the electrostatic interactions between lysozyme and AOT were not altered significantly. Consequently, the extraction mass transfer rate of lysozyme became relatively higher than that of other eggwhite proteins at lower temperatures, thus increasing the specific activity of lysozyme in the extract.

Because of the decrease in extraction temperature, the extraction time was increased to compensate for the reduced mass transfer rate. When the extraction time was extended to $50 \mathrm{~min}$, the recovery rate of lysozyme was $\simeq 90 \%$ (Fig. 4), almost the recovery rate of lysozyme from the standard solution.

The specific activity of the extracted lysozyme could be maintained at a high level within $50 \mathrm{~min}$ of extraction time (Table 3 ). Further increase of extraction time decreased the specific activity of lysozyme, possibly due to increased contact of lysozyme with the organic solvent isooctane, which could inactivate the enzyme.

Electrophoretic patterns of the hen eggwhite, the standard lysozyme solution, and the extracts of these protein solutions by reversed micelles were compared (Fig. 5). The reversed micellar extraction removed the nonlysozyme proteins and yielded a highly purified lysozyme product.

\section{Residual AOT in the extract}

Although the $\mathrm{LD}_{50}$ of AOT is $1900 \mathrm{mg} / \mathrm{kg}$, the residual AOT in the extract may still cause concern if the purified lysozyme were used for food applications. The HPLC we employed could detect AOT as low as $667 \mathrm{mg} / \mathrm{kg}$, but it still did not detect any AOT in the extract. There-



Fig. 2-Concentration of $\mathrm{KCl}$ as related to recovery of lysozyme during reversed micellar extraction.
Table 2-Forward extraction temperature and specific activity of extracted lysozyme

\begin{tabular}{ccc}
\hline Temp $\left({ }^{\circ} \mathbf{C}\right)$ & \multicolumn{2}{c}{$\begin{array}{c}\text { Specific activity (units/mg) } \\
\text { Hen eggwhite }\end{array}$} \\
\hline 5 & Standard lysozyme solution & $63131^{\mathrm{b}}$ \\
10 & $60618^{\mathrm{c}}$ & $70763^{\mathrm{a}}$ \\
15 & $71228^{\mathrm{a}}$ & $68267^{\mathrm{a}}$ \\
20 & $68851^{\mathrm{ab}}$ & $64099^{\mathrm{b}}$ \\
25 & $65617^{\mathrm{b}}$ & $64129^{\mathrm{b}}$ \\
30 & $65873^{\mathrm{b}}$ & $59794^{\mathrm{c}}$ \\
\hline
\end{tabular}

a-cMeans within the same column with different superscripts are significantly different $(\mathrm{p}<0.05)$.

dThe forward extraction time was $30 \mathrm{~min}$

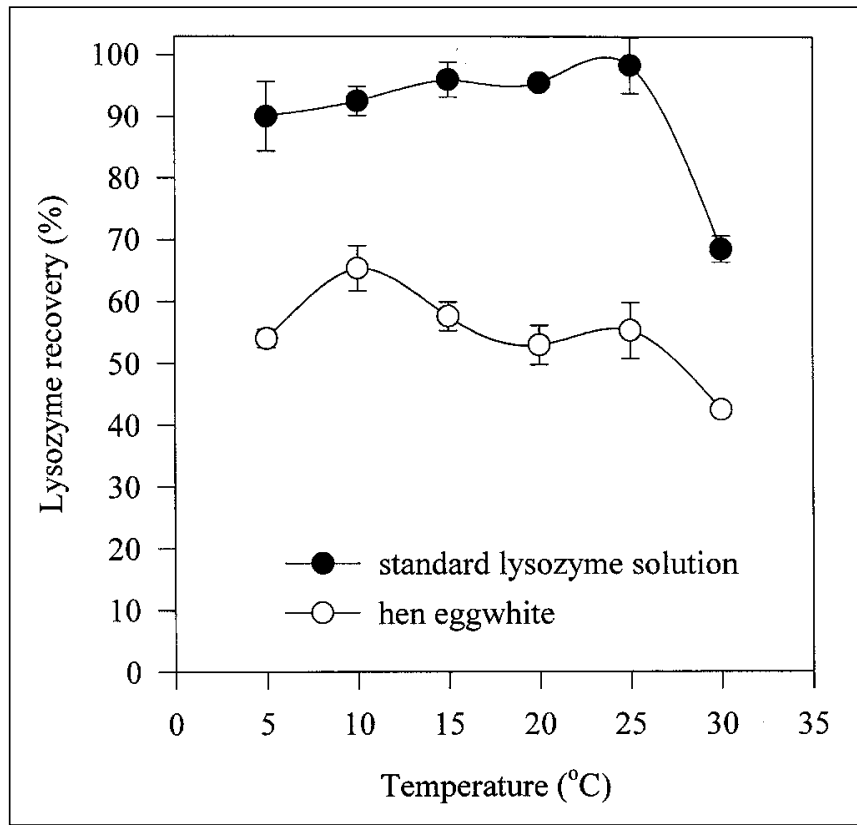

Fig. 3-Temperature effects on the recovery of lysozyme during reversed micellar extraction.

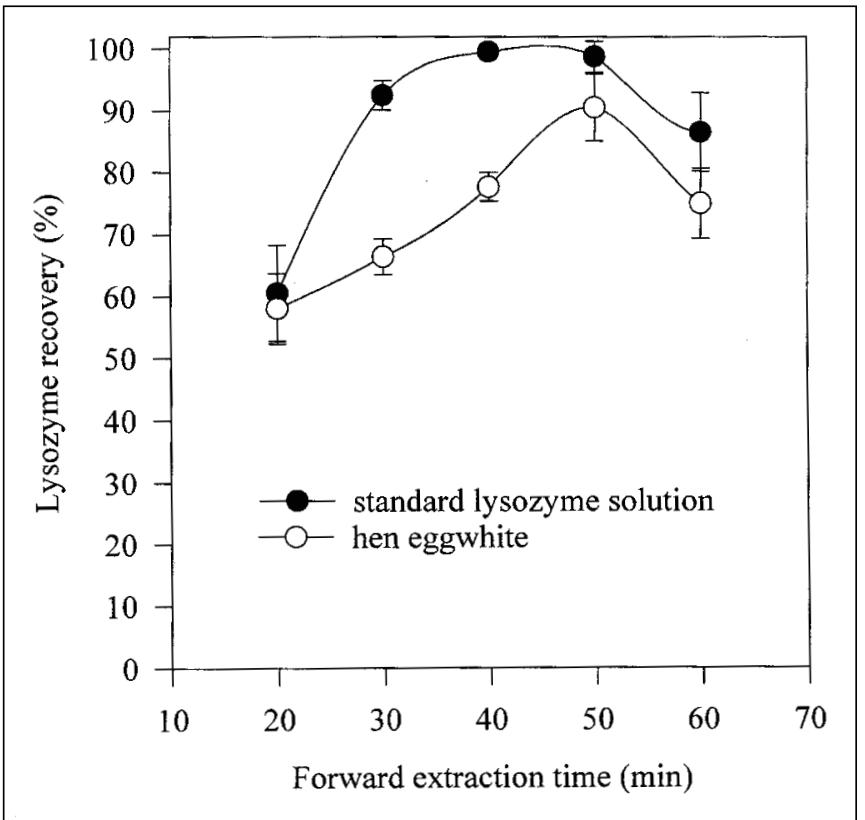

Fig. 4-Forward extraction time effects on the recovery of lysozyme during reversed micellar extraction. 
Reversed Micellar Extraction of Hen Egg Lysozyme . . .

Table 3-Forward extraction time and specific activity of extracted lysozyme

\begin{tabular}{ccc}
\hline Extraction time (min) & \multicolumn{2}{c}{ Specific activity (units/mg) } \\
& Standard Iysozyme solution & Hen eggwhite \\
\hline 20 & $70241^{\mathrm{a}}$ & $69743^{\mathrm{a}}$ \\
30 & $71299^{\mathrm{a}}$ & $72450^{\mathrm{a}}$ \\
40 & $71142^{\mathrm{a}}$ & $72558^{\mathrm{a}}$ \\
50 & $71566^{\mathrm{a}}$ & $73066^{\mathrm{a}}$ \\
60 & $60733^{\mathrm{b}}$ & $62831^{\mathrm{b}}$ \\
\hline
\end{tabular}

${ }^{*}$ The forward extraction was carried out at $10^{\circ} \mathrm{C}$.

** Means within the same column with different superscripts are significantly different $(\mathrm{p}<0.05)$.

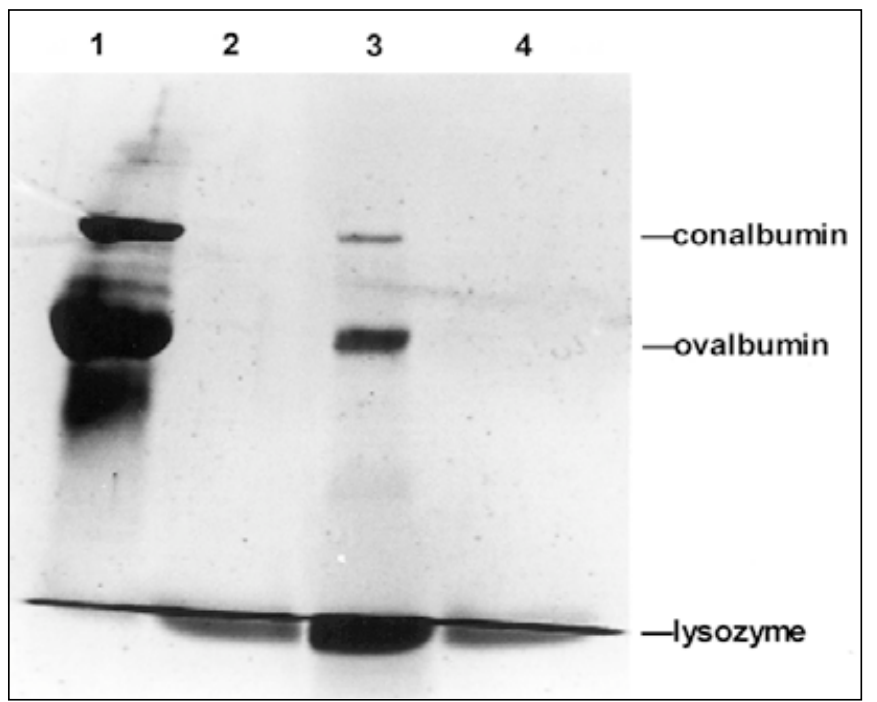

Fig. 5-SDS-PAGE of hen eggwhite proteins during reversed micellar extraction. (1) hen eggwhite; (2) extract from (1); (3) standard lysozyme solution; (4) extract from (3).

fore, we may conclude that AOT was lower than that level, in the lysozyme solution obtained by reversed micellar extraction.

\section{CONCLUSIONS}

LYSOZYME IN HEN EGGWHITE COULD BE EXTRACTED BY REVERSED micelles using an AOT/isooctane system. Eggwhite must be diluted 10 -fold with phosphate buffer ( $\mathrm{pH} 9.2$ ) containing $0.1 \mathrm{M}$ potassium chloride. The extraction was best conducted at $10^{\circ} \mathrm{C}$ for $50 \mathrm{~min}$ and almost $90 \%$ of lysozyme could be recovered. The specific activity of the extracted lysozyme was almost 73,000 units/mg, higher than that of most commercially available lysozyme products.

\section{REFERENCE}

Aires-Barros, M. R. and Cabral, J. M. S. 1991. Selective separation and purification of two lipases from Chromobacterium viscosum using AOT reversed micelles. Biotechnol. Bioeng. 38: 1302-1307.

Bradford, M. M. 1976. A rapid and sensitive method for the quantitation of microgram quantities of protein utilizing the principle of protein-dye binding. Anal. Biochem.

Brandani, S., Brandani, V., Di Giacomo, G., and Spera, L. 1996. Effect of nonlinear equilibrium on the mass transfer rate of $\alpha$-amylase extraction by reversed micelles. Progress Biochem. 31: 249-252.

Chang, Q. and Chen, J. 1995a. Purification of industrial $\alpha$-amylase by reversed micellar extraction. Biotechnol. Bioeng. 48: 745-748.

Chang, Q. and Chen, J. 1995b. Reversed micellar extraction of trypsin: Effect of solvent on the protein transfer and activity recovery. Biotechnol. Bioeng. 46: 172-174.

Chang, Q., Liu, H., and Chen, J. 1994. Extraction of lysozyme, $\alpha$-chymotrypsin, and pepsin into reverse micelles formed using an anionic surfactant, isooctane, and water. Enzyme Microb. Technol. 16: 970-973.

Dekker, M., Riet, H., and Laane, C. 1989. Review: isolating enzymes by reversed micelles. Anal. Biochem. 178: 217-226.

Dekker, M., Riet, K.V., Bijsterbosch, B. H., Hilhorst, R., Baltussen, J.W.A., Jens, J., and Pol, V. D. 1991. Effect of temperature on the reversed micellar extraction of enzymes. Chem. Eng. J. 46: B69-B74

Dekker, M., Riet, K.V., Weijers, S.R., Baltussen J.W.A., Laane, C., and Bijsterbosch, B.H. 1986. Enzyme recovery by liquid-liquid extraction using reversed micelles. Chem. Eng. J. 33: B27-B33.

Duncan, D.B. 1955. Multiple range and multiple F tests. Biometrics 11: 1-42.

Goklen, K.E. and Hatton, T.A. 1987. Liquid-liquid extraction of low-molecular-weight proteins by selective solubilization in reversed micelles. Sep. Sci. Technol. 22: 831841.

Jolivalt, C., Minier, M., and Renon, H. 1990. Extraction of $\alpha$-chymotrypsin using reversed micelles. J. Colloid. Interface Sci. 135: 85-96.

Kato, A., Imoto, I., and Yagishito, K. 1975. The binding groups in ovomucin-lysozyme interion. Ar. Biol. Chem, 39: 541-544.

Kelley, B.D. Wang, D.IC., and Hatton, T.A. 1993. Affinty-based reved micellar Kelley, B.D., Wang, D.I.C., and Hatton, T.A. 1993. Affinity-based reversed micellar protein extraction: Il. Effect of cosurfactant tail length. Biotechnol. Bioeng. 42: 1209-

Kinugasa, T., Tanahashi, S., and Takeuchi, H. 1991. Extraction of lysozyme using reversed micellar solution: Distribution equilibrium and extraction rates. Ind. Eng. Chem. Res. 30: 2470-2476.

Kinugasa, T., Tanahashi, S. I., and Takeuchi, H. 1992. Activity and conformation of lysozyme in reversed micellar extraction. Ind. Eng. Chem. Res. 31: 1827-1829.

Krei, G., Meyer, U., Burner, B., and Hustedt, H. 1995. Extraction of $\alpha$-amylase using BDBAC-reversed micelles. Bioseparation 5: 175-183.

Kunieda, H. and Shinoda, K. 1980. Solution behavior and hydrophile-lipophile balance temperature in the aerosol OT-isooctane-brine system: Correlation between microemulsions and ultralow interfacial tensions. J. Colloid Interface Sci. 75: 601606.

Laemmli, U.K. 1970. Cleavage of structural proteins during the assembly the head of bacteriophage T4. Nature 277: 680-685.

Leodidis, E.B. 1990. Thermodynamics of solubilization in W/O droplet micro emulsions. Doctoral thesis, Dept. Chem. Engr., Massachusetts Institute of Technology. Leser, M.E. and Luisi, P.L. 1990. Application of reverse micelles for the extraction of amino acids and proteins. Chimia 44: 270-282.

Luisi, P.L. 1985. Enzymes hosted in reverse micelles in hydrocarbon solution. Angew. Chem. Int. Ed. Engl. 24: 439-450

Lye, G.J., Asenjo, J.A., and Pyle, D.L. 1995. Extraction of lysozyme and ribonucleasea using reverse micelles: Limits to protein solubilization. Biotechnol. Bioeng. 47: 509-519.

Marcozzi, G., Correa, N., Luisi, P.L., and Caselli, M. 1991. Protein extraction by reverse micelles: A study of the factors affecting the forward and backward transfer of $\alpha$-chymotrypsin and its activity. Biotech. Bioeng. 38:1239-1246.

Nakai, S. and Kason, C.M. 1974. A fluorescence study of the interactions between $\alpha-$ and $\beta$-casein and between lysozyme and ovalbumin. Biochim. Biophys. Acta 351: $21-27$.

Naoe, K., Shintaku, Y., Mawatiari, Y., Kawagoe, M., and Imai, M. 1995. Novel function of guanidine hydrochloride in reverse micellar extraction of lysozyme from chicken egg white. Biotechnol. Bioeng. 48: 333-340.

Nishiki, T., Sato, I., Kataoka, T., and Kato, D. 1993. Partitioning behavior and enrichment of proteins with reversed micellar extraction: I. Forward extraction of proteins from aqueous to reversed micellar phase. Biotechnol. Bioeng. 42: 596-600.

Rahaman, R.S., Chee, J.Y., Cabral, J.M.S., and Hatton, T.A. 1988. Recovery of an extracellular alkaline protease from whole fermentation broth using reversed micelles. Biotechnology Progress 4: 218-224.

Taipa, M.A., Aires-Barros, M.R., and Cabral, J.M.S. 1992. Purification of lipases. J. Biotechnology 26:111-142.

Ms received 4/15/97; revised 11/29/97; accepted 12/20/97. 